\title{
EDITORIAL
}

\section{CONSTITUIÇÃO, REALIDADE E CRISE}

Wilson Steinmetz Editor Assistente da EJJL

"O direito constitucional tem de se garantir por si mesmo", escreveu Konrad Hesse. A observância e a aplicação das normas constitucionais não estão garantidas por outras normas acima da Constituição ou por poderes supraestatais. "A Constituição não depende senão de sua própria força e de suas próprias garantias." (HESSE).

No caso da Constituição brasileira, são garantias imanentes o controle de constitucionalidade das leis, os limites materiais ao poder de emendar a Constituição, o dever de aplicação imediata de direitos e garantias fundamentais e a previsão de um órgão judicial guardião máximo da Constituição, com poderes de decidir sobre matérias constitucionais com efeitos imediatos, gerais e vinculantes.

Contudo, o próprio Hesse lembra que nem o mais "engenhoso sistema constitucional" consegue garantir a sua própria efetividade quando certos pressupostos não estão presentes, especialmente quando a Constituição não consegue ser uma ordem configuradora da realidade histórica viva. Essa capacidade configuradora "[...] depende em grande medida de fatores externos, sobre os quais a Constituição só pode influir limitadamente." Hesse menciona entre os fatores externos as circunstâncias da realidade histórica e o nível de desenvolvimento espiritual, social, político ou econômico dos tempos.

Outro pressuposto essencial, ainda segundo Hesse, é a conduta dos atores que participam na "vida constitucional". Decisiva é a disposição de governantes e governados aceitarem como moralmente correto, legítimo e imperativo o conteúdo da Constituição.

Em síntese, paralelamente às garantias imanentes da Constituição, desempenham um papel decisivo os fatores externos. É a dialética que se processa entre norma e realidade, que se manifesta em complementaridades e tensões.

Tudo isso não é inovação ou novidade teórica. São premissas bem assentadas no campo da Teoria da Constituição enquanto locus epistêmico de análise e reflexão sobre as constituições. O que muda é a descrição ou a interpretação da relação entre Constituição e realidade que cada uma das inúmeras teorias da Constituição propõe e a ênfase, descritiva ou valorativa, que se atribui aos polos da relação.

$\mathrm{Na}$ atual quadra da história do Brasil, retomar a pesquisa e a reflexão rigorosas sobre a dialética Constituição-realidade é, se não uma imposição, muito recomendável à comunidade científica do direito, especialmente àqueles que investigam o direito como fenômeno normativo e suas projeções sobre as relações políticas e sociais. Nosso País vive aquela que talvez seja a maior crise após a redemocratização. À crise política somam-se uma crise econômica e uma crise financeira do Estado, nos três níveis da Federação.

A crise política por si mesma não seria atemorizante ou ameaçadora. Desde a redemocratização em meados dos anos 1980, atravessamos crises políticas sem rupturas institucionais ou cons- 
titucionais. No pós-1988, a Constituição tem se mostrado adequada e, ao mesmo tempo, resistente às crises políticas sazonais.

No entanto, há fundados motivos para supormos que a atual crise - que possui uma dimensão política, uma dimensão econômica e uma dimensão financeira - desafia e continuará desafiando a engenharia institucional e organizacional desenhada pela Constituição de 1988. Primeiro, as dimensões da crise formam uma unidade, estão profundamente imbricadas. Passados dois anos, constata-se que a solução da crise geral depende de uma solução articulada ou encadeada das três dimensões. Segundo, o País necessita de uma ampla reforma política para a qual os partidos, os grupos e as facções políticas parecem ter disposição nenhuma para convergir. Terceiro, a crise sinaliza que o Estado brasileiro, em todas as suas esferas, já não tem condições de, simultaneamente, cumprir todas as tarefas que a Constituição lhe impõe, atender às demandas remuneratórias das corporações internas ao Estado (especialmente, daquelas corporações tradicionalmente privilegiadas) e às demandas de financiamento ou crédito de grupos econômicos e sociais externos ao Estado. Quarto, o País necessita de uma profunda reforma fiscal, mas ninguém quer perder coisa alguma.

Após 1988, a comunidade científica do direito, especialmente aquela dedicada à investigação do direito constitucional, priorizou a exploração e a construção de modelos, interpretações e esquemas argumentativos que otimizassem as potencialidades normativas, substantivas e instrumentais da Constituição. E isso, sem dúvida, produziu um estado da arte muito superior na teoria, na dogmática e na práxis constitucionais àquele anteriormente existente. Desse empenho, resultou, até mesmo, um certo otimismo constitucional.

Aqui, não se está dizendo ou insinuando que o País vive uma crise constitucional ou está na iminência de se precipitar em uma crise constitucional. A Constituição vige. A Constituição, na sua globalidade, não é motivo de dissenso. A Constituição mantém sua legitimidade. Sinaliza-se, isto sim, que talvez estejamos no fim de um ciclo. A crise pela qual atravessamos testará as soluções constitucionais (princípios e regras) que temos para o jogo político, para os direitos e interesses das corporações que movimentam o Estado, para o financiamento dos inúmeros deveres e tarefas do Estado e para o atendimento de interesses de grupos econômico-empresariais e de movimentos da sociedade civil organizada.

Nesse contexto, a comunidade científica do direito não estará cumprindo seu papel ao se limitar tão somente a desenvolver investigações que explorem as potencialidades normativas da Constituição a partir de uma perspectiva internalista; que explorem o direito constitucional apenas a partir dos mecanismos e das garantias imanentes da Constituição. Os problemas e desafios que compõem a crise demandam investigações que também tenham por objeto a dialética Constituição-realidade e as condições fáticas (elementos externos) que interferem na efetividade da Constituição. A adequação empírica das soluções constitucionais deve ser submetida à análise e à crítica, sem preconceitos, mas também sem o propósito de desconstituir aqueles elementos essenciais da Constituição, especialmente os direitos fundamentais e o regime democrático, porque são patrimônios da civilização à qual estamos ligados. Sem que se perca a identidade de juristas, teóricos ou cientistas do direito, será preciso abrir-se e dialogar com outros saberes, como a Ciência Política e a Economia, para citar dois exemplos. 